\title{
Critical Reflections on the Zambian Education System and the Teaching of English in Post-Colonial Zambia
}

\author{
David Sani Mwanza \\ The University of Zambia, Zambia \\ Email: david.mwanza@unza.zm
}

\author{
Article History \\ Received: January 2, 2020 \\ Revised: January 28, 2020 \\ Accepted: February 4, 2020 \\ Published: February 9, 2020 \\ Copyright (C) 2020 ARPG \& Author \\ This work is licensed under the \\ Creative Commons Attribution \\ International \\ (4) (1) CC BY: Creative Commons \\ Attribution License 4.0
}

\begin{abstract}
This paper takes a critical look at the Zambian Education system by focusing on the teaching of English in the country. This is achieved through discussing the structure and organisation of the education system, teacher training and the standard of English to be taught in schools relative to other varieties. By reviewing studies which have been conducted on the teaching of English in Zambia, the paper observes that while remarkable strides have been made in improving the teaching of English, there are a number of issues which need attention. For instance, the recognition of translanguaging and its pedagogic value forms a big part of the argument in this paper.
\end{abstract}

Keywords: English; Teaching; Translanguaging; Teacher training; Education system; Language attitudes.

\section{Introduction}

\subsection{The Education System in Zambia}

In Zambia, there is a three tier education system consisting of primary, secondary and tertiary education. Primary takes the first seven years of formal education while secondary takes five years. Tertiary education differs in duration depending on whether one attends a college or university. College diplomas take three years while university education takes four years of bachelor's degree. Although, this structure is what is currently prevailing in Zambia, the system has seen twists and turns. Thus, from independence in 1964 to 2004, there was primary, secondary and tertiary education. However, when former President Mwanawasa came into power in 2001, the structure of education changed. Primary education changed its name to basic education and the period was extended from grades one to grade nine. Secondary education changed to high school and it took three years from grades ten to grade twelve. It was during this time that primary teachers' colleges started offering three years diplomas in order to produce teachers who would teach at grades eights and nines which had now become part of the basic school. However, when the Patriotic Front took government in 2011, the structure was changed again. The new government reverted back to the earlier structure where primary school was restored which now takes seven years while secondary education was also restored and takes five years. It can be stated that the current structure being implemented by the current government is not new, but rather, a re-introduction of the former structure. Beyani (2013), captures these developments quite neatly when he noted the following:

Until 2005, primary school covered the first seven years and secondary school another five. The tertiary level included four years of university education and two to three years of college education. However, during the Mwanawasa presidency in the 2000s this changed. Primary school was renamed basic education and constituted the first nine years, while secondary school became known as high school education, and was for three years only. Under the new PF government, it has reverted to the post-independence education structure with immediate effect.

It is not very clear why the government of Zambia has been making these changes in the structure of the education system. The challenge is that when the structure changes, a lot of things change as well. For example, when primary schools changed into basic schools, it meant that primary school teachers were supposed to teach grade eights and nines even when they did not possess the qualification to teach those grades. Hence, during the transition period, learners were the victims as they were not taught by qualified personnel. In terms of infrastructure, primary schools needed to be expanded in terms of building more classrooms. From 2005 to 2011, basic schools seemed to have been established and colleges of education started training teachers who would teach at the basic school. Other colleges and universities were training teachers who would teach at high school. By implication, it is reasonable to assume that the curriculum in colleges had changed. Thus, reverting back to the old system required other structural and administrative changes to take place. For instance, it may mean that those teachers who were prepared to teach grades eights and nines may now be qualified to teach at secondary schools. Are high schools ready to accommodate grades eights and nines considering that they were full with grades tens, elevens and twelves?. Once again, learners are inconvenienced and some teachers may be asked to start teaching in schools or 
grades they were not ready for. When all implications are considered, one wonders whether the decisions taken by government are really based on educational principles or mere politicking.

It is important to note that in Zambia, primary education is free. Secondary and tertiary education is paid for. The country boasts of more primary schools than secondary schools and tertiary institutions. This means that fewer learners will progress to secondary schools due to both failure and lack of school places as a result of not having adequate schools. The education sector faces many challenges. Ministry of Education (1977a), mentions lack of school places resulting into over enrolment in schools, lack of teaching and learning materials, shortage of teachers and lecturers, lack of adequate infrastructure as some of the challenges being faced by the education sector. These may appear to be challenges of the past. However, Beyani (2013) also acknowledges the same problems as still facing the ministry of education in Zambia today and he argues that:

This state of affair has had a negative impact on the effectiveness of delivery services at primary, secondary and tertiary levels in education sector. The internal system is very inefficient and characterized by high dropout rates and poor reading and arithmetic skills at middle primary level, as well as generally unsatisfactory examination performance at both primary and secondary levels.

Today, the challenges of inadequate teaching materials, shortage of teachers, inadequate infrastructure, poor reading and writing skills in primary schools and over enrolment resulting into overcrowding in classrooms are still confronting the education system across subject areas in Zambia (Banda and Mwanza, 2017; Bwalya, 2019; Mumba, 2019; Mwanza, 2012;2016).

The situation captured above has very serious implications on the teaching of English. Firstly, the children who are said to have poor reading skills in primary school will have to learn the English subject at secondary school. Since learner centeredness is important to the implementation of the recommended eclectic approach when teaching English (Mwanza, 2016;2017c), teachers are supposed to take this poor language background of the learners into consideration in the choice of methods as well as the manner of teaching. Secondly, poor examination performance is an issue which needs attention. Although it is not specified in Beyani's study whether there is poor performance even in the English subject, it is important to question the role and abilities of the teacher in this. Given the challenges the education sector is facing, an eclectic teacher of English has a duty to still make teaching and learning meaningful and interesting for the learners. This is not to say that eclectic teachers are not affected by education problems, rather, they should be equipped with creative skills and abilities to ensure that learning take place by studying the context, and design teaching according to the factors around a specific teaching and learning context. Their knowledge of Eclecticism will help them how to recontextualise the curriculum and pedagogic through the use of principled eclecticism whether in its simple or complex form Mwanza (2017b).

Since this paper mainly focuses on secondary schools where the teaching of English subject is too elaborate and by extension tertiary education, let me briefly discuss secondary and tertiary education in Zambia. Beyani (2013) observed that "secondary education is the most neglected part of the education sector" in Zambia. This appears to be correct when one considers (Longe, 2003) who noted that secondary schools in Zambia are mired by shortage of teachers and ill qualified ones resulting into poor quality teaching. Further, governments funding has been below expectation such that schools do not have enough classrooms and teaching materials. As mentioned earlier, these challenges still confront the education system and the teaching of English today.

Secondary schools in Zambia are either government, private, grant aided or community owned. Government schools are owned and funded entirely by the government. Private schools are owned by individuals or groups and are registered as companies. Grant aided schools are those which are semi private and receive grants from the government to help in their operations. Community schools are established and owned by the community. In 2004, there were 330 secondary schools. There was a total of 206 government schools, private were 49, the church owned 21 while 7 were unknown (Ministry of Education, 2005). Nine years later, Beyani (2013) indicates that Zambia had 644 secondary schools. Of these, 423 were government, 140 private, 73 grant aided and 8 community schools. This shows that during the period 2004 and 2013, government tried to expand secondary education by building more schools. However, annual reviews and studies (Beyani, 2013; Ministry of Education, 2001;2005;2006;2008) have shown that there are constant challenges in secondary schools such as shortage of teachers, lack of classroom space resulting into overcrowding in classes, poor infrastructure and lack of teaching materials. No doubt, these challenges have the potential to negatively impact effectiveness and quality in teaching. However, the point to note is that these reports are general and give a picture of what is going on across subjects. Thus, it is still not known what challenges teachers of English in particular face. I will attend to this later.

Another point worth stressing is that the number of public Universities in Zambia is too small. At present, there are only seven public Universities (University of Zambia, Copperbelt University, Mulungushi University, Kwame Nkhrumah University, Mukuba University, Levy Mwanawasa Medical University and Chalimbana University). This is clearly not enough for a developing country whose need for skilled and educated workforce cannot be over emphasized. In 1969, the government expressed awareness of the importance of university education when it stated that in order to develop the country, many jobs in the country would require that a person had a university degree or more (Government of the Republic of Zambia, 1969). Based on this sound statement, one would expect that the government would embark on building more Universities in order to realise the dream. Ironically, the government only has seven public universities since independence in 1964 and some of these seven Universities do not train teachers. These are not enough to meet the demand for high education in a country that is so desperate to develop, a goal which requires that most people managing the county's economy possess refined knowledge and skills. Instead, what we have witnessed is the slow but steady increase in the number of private universities which are not 
supervised by government, and therefore, issues of standards and quality may not be certain. In the next section, I provide a discussion on the training of teachers of English in Zambia.

\section{Training of Teachers of English in Zambia}

The training of teachers of English is crucial in Zambia. Teachers undergo either University training (to obtain a degree in English) which takes four years, or College training (to obtain a diploma in English) which takes three years. In both cases, trainee teachers learn English teaching methods for a year and English content is learnt throughout the period of study. During the course of study, they also go for teaching practice during which time, the student teacher practices teaching in a real classroom situation as part of learning. Hence, teaching practice is considered a very important part of teacher training in Zambia.

Beyani (2013), reported that Zambia had 14 colleges of education country wide. Of these, ten trained primary school teachers while two prepared secondary school teachers. The other two were in-service teacher training institutions. The University of Zambia has a school of education which also train both primary and secondary school teachers. Other colleges are Natural Resources Development College which train teachers in agriculture science and Evelyn Hone College which among others, also train teachers of Art, Music and English (Beyani, 2013; Longe, 2003; Ministry of Education, 2007). Clearly, the number of teacher training institutions is not enough to produce the required number of teachers to address the problem of shortage of teachers in schools. In fact, inadequate training institutions appear to be the central problem where most of the pedagogical problems emanate. The problem is worsened by the fact that there is also a problem of teacher attrition and the impact of HIV /AIDS (see MOE 2007, 2008). Inevitably, there is need for the government to build more teacher training institutions in order to produce more teachers. This is so because shortage of teachers implies that the available teachers are overworked. Ironically, the few teachers who graduate are not deployed due to what are thought to be financial constraints by government. Arising from the preceding challenges, quality of teaching and learning is compromised as learners may only have access to the classroom but not learning itself

All government teacher training institutions are affiliated to the University of Zambia. In this arrangement, the university is supposed to ensure that these colleges deliver the content and methods according to the senior secondary school syllabus as well as the current trends in English language teaching. This implies that there is uniformity on major themes in teacher education across all colleges in Zambia. Since the eclectic approach is the recommended method in the secondary school English syllabus (Curriculum Development Centre, 2012; Mwanza, 2016), it is expected that all colleges in Zambia introduce their teachers to the eclectic approach. The question that begs attention is how well does the University of Zambia (UNZA) perform its role. Longe (2003), noted that UNZA faces a lot of challenges such as poor funding and that this affects its role of ensuring quality and high standard in colleges of education. Once again, government's weakness in managing the education system is exposed. As a coordinator and general overseer of teacher training in the country, the University of Zambia is supposed to be adequately funded so that colleges may also benefit from the expertise and skills of University of Zambia teacher educators. In any case, this is the collaboration which would ensure consistence and uniformity in terms of standards and quality in all the colleges of education.

The country also has private teacher training institutions. However, as Beyani (2013) observed, government has no autonomy over these colleges. They do most of the things on their own. This means that issues of standards and quality are not closely monitored. The eventual effect is that teachers who graduate from these colleges and Universities may be of low quality and pedigree to teach effectively and competently in secondary schools.

In terms of how teachers are trained in content, methods and the qualities of a teacher, it is easy to decipher that the goal of the Ministry of Education is to produce an informed teacher and one who is eclectic in terms of teaching methods. The 1977 education reforms document is very helpful in unpacking this matter. The goal of teacher training is to impart knowledge and skills into a teacher which is up-to-date with current developments in the field of teaching as well as the country's social economic situation. Teacher education is based on the identified needs and aspirations of the country (Ministry of Education, 1977a). From the perspective of teaching methods, this means that teachers should be informed of the current methods of English language teaching and should be able to use them according to the prevailing conditions of the classroom, the school and the country in general. This is part of the explanation of what an eclectic teacher of English should be.

In addition, teacher training programmes in Zambia are intended at building a teacher with the right attitude, personality, ethics and knowledge of what teaching and learning is all about. In order to do so, teacher training programmes include subjects such as educational psychology, education sociology, general education, guidance and counselling and other supporting subjects other than the major teaching subject (Ministry of Education, 1977b). As mentioned above, the goal here is to come up with an all-round teacher who is versatile enough to deal with the complexities of the classroom. From what I consider as government's directive for colleges of education to produce an eclectic teacher, (Ministry of Education, 1977b) notes that:

teacher education should assist the teacher to develop his planning and instructional skills through the use of a variety of techniques and teaching methods. It should also develop his organisational and management abilities, awareness and understanding of learners needs.

From the above quote, the ability to identify learners' needs and be able to use a variety of teaching techniques and methods according to their varying characteristics surely means that teacher training institutions should train eclectic teachers. Suffice to mention that, Eclecticism involves the use of a variety of techniques, methods, and materials based on the fact that different learners in the classroom have different learning needs and abilities. Thus, 
from the quote above, one can tell that the government of Zambia through the ministry of education intends to train eclectic teachers.

In addition, the government intends to train teachers who have multiple skills to handle the complex job of teaching. Teachers should be professional in conduct while also being knowledgeable and competent in the subjects they choose to teach. This is so because teaching demands both professional and academic skills. Further, teachers should be researchers. This means that they should continuously build on the knowledge and skills they acquire in colleges and universities. They should not be satisfied and limited to what they learn in class during teacher training; rather, they should strive to read and be aware of the new developments in the field of teaching. This calls for teachers' creativity and continuous self-development. This is partly so because the teaching profession is in continuous development and change. All these qualities and abilities are expected of Zambian secondary school teacher. For example, consider the following quote:

The teacher cannot play his various roles successfully from a position of mediocrity. Good teaching demands that the teacher should not only possess a correct attitude and adequate knowledge of the subjects he teaches but also keep abreast of developments in those subjects and in the objectives and methods of teaching (Ministry of Education, 1977a).

Teaching from a position of mediocrity needs discussion. It must be noted that even a teacher who claims to be eclectic can do so from a position of mediocrity. For example, unprincipled eclecticism where a teacher will select and use methods without considering the needs and special characteristics of the learners (Mwanza, 2017a) definitely amounts to mediocrity. If a teacher fails to motivate and help learners learn equally amounts to mediocrity. Further, teachers who lack a positive attitude, professional ethics in the conduct of teaching and who lack knowledge on the various methods of teaching and in what contexts and topics those methods work may rightly be deemed mediocre. Therefore, it is reasonable to agree with the government that mediocrity should not have a place in the Zambian teaching service, and that training a competent, ethical and well informed teacher is the right objective of teacher training. To this end, an eclectic teacher (who is the goal of the government) should be competent in both the content and methods of teaching as well as professionally endowed in order to manage learners with their diversities.

A study was done in selected secondary schools in Lusaka by Kayungwa (2002) whose purpose was to establish the qualities of a good teacher as perceived by learners and teachers themselves. The study showed that effective teachers are those who are knowledgeable, competent, prepare for lessons, give clear explanations in class, lively, creative, loving and approachable. Moreover, the Ministry of Education in Zambia hopes to have motivated teachers who can in turn motivate learners to learn. However, Mutono (2010) in her study on factors affecting teacher motivation in selected secondary schools in Lusaka cited low salaries, lack of accommodation, lack of promotion opportunities and lack of teaching/learning materials as some of the causes of low motivation among teachers.

Another important issue the Ministry of Education is interested in is the quality of lecturers in colleges and universities who train teachers. It is believed that quality teachers are products of quality training which emanates from quality teacher educators. This means that lecturers in colleges of education and Universities training teachers should be competent both in content and methodology. They need to understand what teaching and learning is about including what can help learners learn through the various methods and what classroom activities enhance learning in particular situations. Lecturers should themselves possess the right attitude and high level professionalism if they want their products to be professional and successful teachers once they go to teach in secondary schools. It is common belief that teachers normally a reflect those who taught them in training institutions. Whether this is true of not, the point is that teacher educators should be competent if they are to produce competent teachers. In line with this argument, (Ministry of Education, 1977a) believes that:

A good teacher is not a product of chance. He is a product of good education both academically and professionally...this among other things, implies that those who educate and train our teachers must themselves be highly competent and of superior quality.

In the context of this paper, it is clear that the ministry of education in Zambia expects lecturers in teacher training institutions to be competent and professional. They are expected to be knowledgeable of the various teaching methodologies and techniques and how they are applied in teaching. They are expected to have thorough knowledge of the secondary school English syllabus, to be aware of the recommended methods and be able to tailor their training according to the needs and objectives of the English secondary school syllabus. To be of superior quality also means being resourceful and possess the skills and abilities to produce and reproduce teaching and learning materials. It is therefore expected that teacher educators (lecturers) in Zambia have adequate knowledge of the content of the subject, methods and the syllabus. Since they are researchers, they are expected to have wide knowledge of the various teaching contexts in the country and be able to provide advice and mentorship to trainee teachers on how they can go about teaching in those different contexts when they are deployed in schools after training.

So far, it has been established that the ministry of education in Zambia through government policy documents expect colleges of education to come up with teachers who are eclectic in knowledge and practice. Infact, the senior secondary school English language syllabus makes recommendations specifically on how English should be taught. The point to make clear at this point is that the 1977 education reforms on teacher education and all the English languages syllabus including the most recent syllabus which was revised in 2012 agree on the principles of good teaching. The syllabus in its recommendations is even more direct on suggesting the eclectic approach in the teaching of English. The secondary school English syllabus recommends the concurrent use of the communicative approach and the text based integrated approach (Curriculum Development Centre, 2012) which Mwanza (2016) viewed as Eclectic. In fact, regarding the teaching of listening and speaking, (Curriculum Development Centre, 
2012) states that it is the duty of the teacher to choose and use methods which may best enhance learning. It is therefore clear that the ministry of education both in its general teacher education goals and on how teachers of English should teach English expect the eclectic approach to be the method of use see also Curriculum Development Centre (2012).

Although teacher education in Zambia seems to be founded on very strong grounds, research has shown that generally, teacher training is problematic in Zambia. Manchishi and Mwanza (2013), found in their research on the adequacy of teacher training at the University of Zambia that most student teachers had problems with lesson delivery. They were not able to put theory learnt during training into practice in the classroom. Another study was conducted by Manchishi and Masaiti (2011) whose aim was to establish if the University of Zambia pre-service teacher education programme was responsive to secondary schools and the aspirations of the communities. They also found weaknesses in the content and methodology of the teacher education programmes. Trainee teachers were unable to apply the broad content learnt and the methods of teaching into real classroom situation. They noted that the problem was with the teacher education programme which needed to be revised if it was to respond to the needs of secondary schools. The mismatch between what was taught at UNZA and what was obtaining in secondary schools meant that teachers had problems fitting in secondary schools because their abilities, skills and attitudes were not of the required or expected standard. Consider the following quote:

There were gaps between what the UNZA programme was offering and what was obtaining in the High Schools. There is evidence that UNZA trainee teachers were exposed to a broad content material which, in some cases, did not take into consideration what was obtaining in the Zambian High Schools.... The study also revealed that UNZA prepared teachers who were weak in the delivery of subject matter (methodology) and that Professional ethics were not part of UNZA Teacher Education Programme (Manchishi and Masaiti, 2011).

The weaknesses associated with the University of Zambia regarding teacher education are a great source of concern. This is because as stated above, all other teacher training institutions are affiliated to the University of Zambia. The assumption behind the affiliation is that UNZA should help the Ministry of Education in ensuring quality and high standards in colleges of education. In fact, concerning the affiliation, (Ministry of Education, 1977a) noted that "the relationship represent one of the many ways in which the University of Zambia continues to exert its educative influence" on other teacher training institutions. However, with the findings above, one wonders what influence in terms of quality and standards UNZA has on colleges of education when its own teacher education programme is problematic. UNZA seems to be struggling to operate as an example to other teacher training institutions and this may have an impact on the quality and standards which come out colleges.

As hinted above, the status and functions assigned to English mean that it is arguably the most important language officially. Since it is the language of formal employment, communicative competence in English is mandatory to getting a job especially in the public service (Wakumelo, 2013). It therefore follows that teacher training institutions are preoccupied with producing good teachers of English who are later entrusted with the responsibility of preparing a cohort of English communicatively competent citizenry that will occupy decision making positions in the country. It is therefore important that government invests in both tertiary institutions training teachers and secondary schools where the teaching of English is taking place. This can be done through the provision of financial and material support to various institutional stake holders in order for them to perform their roles effectively and successfully. Good teacher preparation is not accident or coincidence, it is a product of deliberate administrative decisions and clear procedures and guidelines. In order for this to happen, government has to work together and support all stakeholders in the provision of education in Zambia especially teacher training institutions and secondary schools. At the centre of this is the University of Zambia which provides quality assurance services in colleges of education in the country.

\section{Varieties of English in Zambia}

Zambia has an estimated population of 17 million people. Wakumelo (2013), noted that according to the 2010 census where the population of Zambia was estimated to be 13 million, only $1.7 \%$ of Zambians spoke and understood English. This means that most of the population in Zambian predominantly speak Zambian languages see (Central Statistics Office, 2010). Zambia has 73 dialects which can be collapsed into between 25 and 40 mutually intelligible languages. Nkosha (1999), observed that "Zambia has no national lingual-franca although it uses seven (7) regional indigenous languages, which are widely understood and used in the regions". However, different people speak different varieties of the same language. For example, Mwanza (2012) observed that while the standard forms of the seven regional languages exist in written form and spoken only in selected parts of the country, other areas especially urban spaces speak 'town dialects' of the language which is characterised with borrowing and translanguaging as the common language practice. Banda and Mwanza (2017), noted that due to language contact and globalisation, there has been a growing development of informal varieties of Zambian languages alongside other dialects in Zambia. Thus, the standard varieties as prescribed in text books are not the only used forms of Zambian languages. It is within this linguistic context that English is an official language and a compulsory subject in Zambian secondary schools.

It could be argued as Ohannessian (1978b) notes that even if there was commitment to have universal education in mother tongues after Zambia's independence in 1964, it would not have worked as missionary education was desperately inadequate and did not prepare Zambians for expert teaching in various content subjects using indigenous languages in primary and secondary school. A study of the teaching of Zambian languages in schools and colleges after 1964 found that teachers and lecturers had little or no linguistic knowledge of the languages they were teaching, and more alarming was the discovery of the "extreme meagreness of linguistic content in courses as 
regards material in and about these languages." Ohannessian (1978b) This appeared to force teachers to teach Zambian languages in English.

In spite of African majority rule after independence, Zambia was still reliant on mission schools and expatriate staff who taught in English. The government introduced the New Primary Approach (NPA) to teaching with the onset of the English medium of instruction in 1965-66. As Banda (2009) notes, the NPA, modelled on Kenya's New Peak course, was touted as a new approach designed to discourage the mechanistic grammar translation and the audio lingual approaches to language teaching/learning ubiquitous during colonial times. The NPA was supposed to enhance English communication skills in learners by emphasising the situations and contexts in teaching. It emphasised group work among learners rather than the teacher being at the centre of the lesson. As Banda (2009) argues, this promoted the "Zambianisation" of English as learners developed their own accents often quite different from their (white) teachers. He further notes that after 1975, the teaching of English increasingly was in the hands of Zambians.

Today, there are two broad varieties of English being spoken in Zambia, namely, formal and informal varieties. Tripathi (1990), observed that in as far as the use of English is concerned there is a growing use of an informal variety of English amongst the English speaking minority which differs phonologically, semantically and syntactically from the standard British English. For example, Bobda (2001) argued that in Zambia, the prevalence of /a/ is very low. It seems to be associated orthographically with 〈ur〉 and 〈our〉 in words such as burn, purpose, burden and journey. Interestingly, Tripathi (1990) argues that even with comprehensive educational intervention, it will be impossible for standard British English to become a norm of spoken usage in Zambia. However, he acknowledged that a much smaller population of the Zambian elite now speak and write like educated Englishmen.

Considering the arguments above, it is important discuss the norm of English or the English variety which should be taught in Schools. Thus, if the majority of Zambians speak the English variety which differs phonologically, syntactically and semantically from the British standard variety, then the norm of English variety in schools should consider the variety spoken by the majority of Zambians. In other words, the English variety taught in Zambia should be or pay respect in a small or bigger way to the one commonly spoken. Interesting, the syllabus does not state explicitly what the norm of English variety should be taught in Zambia. For example, one of the general objectives on listening and speaking English, the syllabus states that learners should be able to "understand and speak English at an acceptable international standard" (Curriculum Development Centre, 2012). The phrase 'international standard' is not clear and is not specific on which international standard teachers should consider. This ambiguity in the syllabus is not sound as it may make teachers interpret the same syllabus differently.

Although Zambia has two English varieties, it must be noted that within the informal variety, there are several sub-varieties. Since Zambia is highly multilingual, different people speak English differently phonetically and phonologically depending on how strongly they are influenced by their respective mother tongue. Within the scope of this argument, the Tonga speaking people will pronounce the $[\mathrm{s}$ ] in because as /s/, while the Chewa speaking people pronounce it as /z/. In addition, while [h] is silent among the Bemba speakers in words such as 'how' and 'here', it is not silent among the Chewa and Tonga speaking people. The point here is that even within the informal variety, there are sub varieties according to the mother tongue interference in particular people see (Mwanza, 2016;2017c).

Considering that different languages and varieties are spoken in Zambia, the question that begs attention is: how should English be taught in the context of multilingualism and multiethnicity? Lewis et al. (2012), state that in a multilingual classroom, there is need to bridge the home and school environment by drawing on the child's linguistic resources to help learners maximise their understanding and classroom performance. Banda and Mwanza (2017), also argue that if the goal of teaching is to enable learners to access learning, then it is imperative that their home languages and literacies are allowed in the classroom as stepping stones to accessing learning. This may involve what is called translanguaging and Lasagbaster and Ofelia (2014) argues that as a pedagogical practice, translanguaging entails allowing students to draw from their home languages in the process of learning the target language and teachers accept it as legitimate pedagogical practice. As Creese and Blackledge (2015) put it "translanguaging as a pedagogy has the potential to liberate the voices of language minoritised students". This means that pedagogically, learners should not be discriminated against from participating in classroom interaction simply because they cannot speak the target language or because they speak a variety different from the 'standard variety'. Thus, to enable all learners access learning, it is important that teachers are flexible in their approach to teaching. As Creese and Blackledge (2015) have stated above, this will entail that all the learners including those with low English proficiencies will be liberated to actively take part in classroom interaction thereby enabling them to access learning. While Hélot and Young (2006) observed that "most teachers are used to implementing top-down policies since they work under the authority of inspectors whose job it is to make sure such policies are put into practice", Cummins (2015) argues that teachers have the pedagogical freedom in their classroom to come up with classroom activities and practices which would promote learning among learners from linguistically diverse backgrounds. This means that even in the presence of Zambia's education policy where English is the sole language of instruction in secondary schools, teachers have the pedagogical freedom to permit learners linguistic repertoires and use them as resources to promote learning.

According to the general objectives of the senior secondary English syllabus on the teaching of structure (grammar), the syllabus recommends that "the teaching of structure at senior secondary school level should be based on errors which occur in learners' spoken and written work" (Curriculum Development Centre, 2012). This means that learners should speak and write English with grammatical accuracy and correctness. However, the question which seeks an answer is: since different languages and dialects spoken by different learners have their own 
grammars, how should English grammar be taught in the context of multilingualism? Following the discussion above about translanguaging as a pedagogical practice and the need to move from the known to the unknown as well as connecting the home with the school in the process of learning, it follows that the teaching and learning of English grammar will recognise the grammars of the languages which learners come with to the classroom and use them as resources in the process of learning English grammar.

As a way forward, contrary to teachers' claims that they are or should teach British English in Zambian schools (Mwanza, 2016), the norm of English Variety to be taught in Zambian secondary schools should be Formal English modelled on British English grammar. Phonetically, it is not possible to teach British English in Zambia because even teachers and teacher educators in Zambia do not speak Received Pronunciation (Mwanza, 2016). When the syllabus mentions international standard, the phrase 'international' standard should be seen in terms of communicative competence in which case speakers of English should possess enough language to communicate both correctly and appropriately context by context. Language variation in terms of accent is a norm and part of modern communication. Further, the use of translanguaging does not mean that teachers will not have one variety they will teach. Rather, teachers will still teach a particular chosen variety but will translanguage in order to allow multiple voices to be heard in the process of teaching and learning.

\section{Studies on the Teaching of English in Zambia}

English is an official language in Zambia, a medium of instruction in schools from grade 5 up to tertiary education and it is the only language subject which is a compulsory subject from grade 1 to the final year of secondary education. To get an insight into the various issues surrounding the teaching of English in Zambia, I now present a review of a number of studies below:

Munakampe (2005), conducted a study to establish the level of implementation of the communicative approach to English teaching at grade 5 and the possible constraints faced by teachers. The findings of the study showed that teachers were not implementing CLT and they didn't understand the underlying psychological processes of language learning. Further, learners did not participate actively in the lesson and the lesson lacked communicative activities. This is study is important in as far as it gives us that some teachers in Zambian at primary school are not aware of the important features of CLT. However, while Munakampe attributed the non-implementation of CLT to lack of knowledge on the part of teachers, the study can be criticised for targeting grades 5 because at that level, most children in Zambia are not proficient in English (cf. (Mulenga, 2012). In fact, this point was raised in her literature review section but she ignored it. Another study was conducted by Mbozi (1989) who sought to investigate the factors which contributed to disparities in grade 12 English results between grant aided schools and government schools. This was based on the observation that grade 12 results in English were better in grant aided than in government schools. The study reported that the quality of teachers and learners was a huge contributing factor to success in the learning process. This means that the quality of teachers and learners contributed significantly to a successful learning and teaching experience.

Sidambi (2011), observed that learners in Zambia completed grade 12 with very poor composition writing skills. He therefore conducted a study to find out how composition was taught in the classroom. Data was collected through interviews and classroom observation. The study revealed that teachers lacked knowledge of the important considerations in the teaching of composition. In addition, out of the 12 teachers whose lessons were observed, only 2 used the right procedure while 8 used a wrong one. The study recommended that teachers needed refresher courses on the teaching of composition.

Sakala (2012), conducted an interesting study to establish the factors which contributed to the excess use of the lecture method of teaching among high school teachers in Kitwe and Kalulushi Districts. The major findings of the study were that teachers excessively used the lecture method due to large class sizes, wide syllabi, lack of teaching/learning materials, the need to prepare learners for examination, lack of participation by learners and the teacher training programme where the lecture method was used predominantly. However, I wish to argue that the reasons given in this study for the use of the lecture method are not justifiable. For example, stating that they used the lecture method because lecturers during training used it is tantamount to lack of pedagogical knowledge on the part of teachers. It is widely understood that lecturers predominantly use the lecture method. This does not become prescription for what teachers will use in secondary schools. A similar study to Sakala was done by Lungu (2006) who investigated the effectiveness of traditional methods on one hand and communicative approaches on the other hand. According to the study, traditional methods included grammar translation method, direct method and the audio-lingual method. Communicative approaches comprised of the cognitive code approach, the situational approach, text based integrated approach and CLT. An experiment was conducted where one class of grade 8 was taught using traditional methods for a term and another class was taught using communicative approaches for the same period of time. The two groups were tested in reading and writing skills before and after the experiment. Results showed that learners who were taught using communicative approaches performed better than those who were taught using traditional approaches. The findings of the study confirmed a widespread recognition for the effectiveness of communicative approaches. However, it can be criticised for limiting the causes of bad or good performance to the choice of methods. It is agreeable that the methods one uses may have a bearing on the teaching outcome but a lot of other factors such as the quality of learners, quality of teachers, teachers attitudes towards traditional methods and communicative methods respectively and the learning environment could also be explanations for the disparity in performance among learners.

Mumba (2019), conducted a study in the copper belt province to establish and analyse teachers understanding and application of the Text Based Integrated Approach to Language Teaching. This was following an observation 
that while the Communicative Language Teaching Method had been studied extensively, the Text Based Integrated Approach had not been studied despite being a recommended method in the syllabus alongside CLT. The findings were that while some teachers demonstrated a fair understanding of the method, the majority held misconceptions and generally lack knowledge of the method. Further, teachers could not apply the method correctly and appropriately. Some of the factors which affected the application of the Text Based Integrated approach included Lack of teaching and learning material, pupils' poor language abilities, lack of teacher preparation to use the method and poor reading culture.

In the same year, Banda (2019) conducted a study in Central Province of Zambia whose aim was to analyse the language practices in selected English language inclusive classrooms. The sampled inclusive classrooms consisted of pupils who could only use sign language and those pupils who used verbal language. Banda wondered what language practices were used to ensure that both groups of learners accessed learning. The findings revealed that while some teachers were familiar with both sign language and spoken language and that they translanguaged, other teachers could only use spoken language. In this case, language interpreters were used. The weakness observed in the lessons especially where interpreters were involved was that sign language interpreters were not trained teachers. This meant that they were only transferring information as a lay person without teaching skills. Further, in terms of interaction between the two groups, it was observed that pupils interacted in the classroom but were in isolation outside the classroom. A critical analysis reveals that while in class, the two groups of pupils are simply forced to stay together as exhibited by the amount of isolation outside the classroom where they have the autonomy to decide their interaction. Some of the topics which were taught included homophones. Banda and Mwanza (2020) argued that infact, inclusive classrooms in Zambia were actually exclusive because the syllabus content and classroom interaction were modelled on spoken language. Thus, even if sign language users were physically in the classroom, they were symbolically violated as they had no access to the content and eventual learning.

The message from the review of literature is that teachers are trying to provide instruction in different ways context by context. However, there are challenges confronting the teaching of English. These include lack of teaching and learning materials and lack of knowledge by teachers to understand and apply certain methodologies. This has brought to light the quality of teacher training they undergo. The quality of pupils and their lack of proficiency in English also affects how teachers design and implement their teaching. In terms of solutions to these challenges. There is need for teacher training institutions to employ hands on instruction to training teachers. In this way, teachers will be equipped with the theory, but most importantly, they will have the practical skills required for teaching. As Manchishi and Mwanza (2016); Manchishi and Mwanza (2013); Mwanza (2018) teachers should be trained according to the needs of the school and learners. This implies improve the quality of teacher training while providing refresher courses to the in-service teachers so that they can also acquire the most important components. Further, while the government should provide teaching and learning materials, teachers are supposed to be equipped with the skills of semiotic remediation and resemiotisation in order for them to have the skills to manipulate objects into teaching and learning materials.

Finally, it was observed that there is symbolic violence should be counteracted by the adoption of translanguaging by teachers.

\section{Conclusions}

In this paper, it has been shown that Zambia follows a three-tier -in- education system. Regardless, the system at all levels is faced with challenges which should be solved in order to improve quality teacher training and quality teaching in secondary schools.

\section{References}

Banda, 2009. "Mission societies and language education policy in Africa: Focus on zambia since 1884. The role of missionaries in the development of african languages." In Prah, K.K (ed.). Cape Town: CASAS. pp. 161-94.

Banda (2019). Analysis of alnguage practices in inclusive english language classes of selected secondary schools in centrale province. MEd Thesis, Lusaka: University of Zambia.

Banda and Mwanza, D. S. (2017). Language-in-education policy and linguistic diversity in Zambia: An alternative explanation to low reading levels among primary school pupils. In $b$. (. Khulupirika, selected readings in education. University of Zambia Press: Lusaka. 109-32.

Banda and Mwanza, D. S., 2020. "The idea was that those who were trained needed to teach others, critical reflections on the 2014 Zambian language of initial literacy policy change." In Ashraf Abdelhay, Sinfree B. Makoni and Cristine G. Severo (eds) Language planning and policy: Ideologies, ethnicities and semiotic spaces of power. Cambridge: Cambridge Scholars Publishing. pp. 125-54.

Beyani, C. (2013). Zambia: Effective delivery of public education services. Johanesburg: Open Society Initiative for Southern Africa.

Bobda, A. S. (2001). East and southern African English accents. World Englishes, 20(3): 269-84.

Bwalya, V. (2019). Democratization of the classroom through teachers' language choices and practices in multilingual classrooms of Zambia. International Journal of Humanities Social Sciences and Education: 60-73. Available: http://dx.doi.org/10.20431/2349-0381.0605006

Central Statistics Office (2010). 2010 census report. Government of the republic of Zambia.

Creese, A. and Blackledge, A. (2015). Translanguaging and identity in educational settings. Annual Review of Applied Linguistics, 35(2015): 20-35.

Cummins, J., 2015. "The social construction of identities: Reflections on 21st century education in light of the charlie hebdo slaughter." In Dragonas, t., gergen, k.,, mcnamee, s. and tseliou, e. (eds). Education as social construction: Contributions to theory, research, and practice. Worldshare books. 
Curriculum Development Centre (2012). Senior secondary school english language syllabus. Lusaka: CDC.

Government of the Republic of Zambia (1969). Zambian manpower. Office of the Vice - President: Lusaka.

Hélot, C. and Young, A. (2006). Imagining multilingual education in france: A language and cultural awareness project at primary level. In o. García,t. Skutnabb-kangas, and m. T. Torres-guzmán, (eds.),imagining multilingual schools. Languages in education and glocalization. England: Multilingual Matters: Clevedon. 69-90.

Kayungwa, L. J. (2002). Qualities of an effective teacher as perceived by grade 12 pupils and teachers in selected secondary schools in Lusaka. Unpublished Master's Dissertation. University of Zambia.

Lasagbaster, D. and Ofelia, G. (2014). Translanguaging: Towards a dynamic model of bilingualism at school / translanguaging: Hacia un modelo dinámico de bilingüismo en la escuela. Culture and Education, 36(3): 557-72.

Lewis, G., Jones, B. and Baker, C. (2012). Translanguaging: Developing its conceptualisation and contextualisation. Educational Research and Evaluation, 18(7): 655-70.

Longe, R. (2003). National capacity building of lead teacher training institutions- a mission to Zambia. UNESCO.

Lungu, E. C. (2006). The effectiveness of communicative approaches and traditional methods on reading and writing achievement in english in grade eight in selected Zambia basic schools. Unpublished PhD Thesis. The University of Zambia.

Manchishi, P. C. and Masaiti, G. (2011). The university of zambia pre-service teacher education programme: Is it responsive to schools and communities ${ }^{e e}$ aspirations? European Journal of Educational Studies, 3(2): 311-24.

Manchishi, P. C. and Mwanza, D. S. (2013). The university of zambia school teaching experience: Is it effective? Journal of Excellence in Higher Education, 4(2): 61-77.

Manchishi, P. C. and Mwanza, D. S. (2016). Teacher preparation at the university of Zambia: Is peer teaching still a useful strategy? International Journal of Humanities Socia Sciences Educations, 3(11): 88-100.

Mbozi, E. M. (1989). Factors contributing to disparities in school certificate results in English. A study of some selected schools in Zambia. Unpublished Masters Dissertation. University of Zambia.

Ministry of Education (1977a). Educational reform: Proposals and recommendations. Government of the Republic of Zambia Printer: Lusaka.

Ministry of Education, 1977b. "Zambian languages: Orthography approved by the ministry of education." In Lusaka: Neczam.

Ministry of Education (2001). Ministry of education annual report. Republic of Zambia.

Ministry of Education (2005). Educational statistical bulletin. Republic of Zambia.

Ministry of Education (2006). Educational statistical bulletin. Republic of Zambia.

Ministry of Education (2007). Educational statistical bulletin. Republic of Zambia.

Ministry of Education (2008). Educational statistical bulletin. Republic of Zambia.

Mulenga, A. (2012). Grade three (3) pupils' preparedness for the read on course (roc): A case of selected basic schools in chingola district of Zambia. Unpublished Masters Dissertation. University of Zambia.

Mumba, C. (2019). Teachers' implementation of the text based integrated approach (tbia) to grade 11 pupils in teaching English in selected secondary schools in Luanshya. Unpublished masters dissertation, Lusaka, university of Zambia. Unpublished masters dissertation, Lusaka, university of Zambia.

Munakampe, Y. H. (2005). A critical appraisal of the communicative approach in selected lusaka basic schools. Unpublished Masters Dissertation. The University of Zambia.

Mutono, V. (2010). Factors affecting teacher motivation in zambia: The case of selected high schools of lusaka province. Unpublished Master's Dissertation. University of Zambia.

Mwanza, D. S. (2012). The language of initial literacy in a cosmopolitan environment: A case of cinyanja in Lusaka district. Unpublished Masters Dissertation, School of Education, University of Zambia.

Mwanza, D. S. (2016). A critical reflection on Eclecticism in the teaching of English grammar at selected Zambian secondary schools. Unpublished PhD Thesis. University of Western Cape, South Africa.

Mwanza, D. S. (2017a). Implications of teachers' attitudes towards unofficial languages on english language teaching in multilingual Zambia. Zambian Journal of Language Studies, 1(1): 101-24.

Mwanza, D. S. (2017b). The eclectic method to language teaching: Clarifications and conceptual extensions. Journal of Lexicography and Terminology, 1(2): 1-24.

Mwanza, D. S. (2017c). Teachers' understanding and attitudes towards the eclectic method to language teaching in Zambia. Journal of Educational and Management Studies, 7(1): 01-16.

Mwanza, D. S. (2018). A critical reflection on eclecticism in the teaching of english grammar at selected Zambian secondary schools. PhD Thesis: University of the Western Cape.

Nkosha, D. C. (1999). A case of Zambian languages in our schools. Unpublished Research Paper Submitted to the Ministry of Education. Lusaka.

Ohannessian, S., 1978b. "The teaching of Zambian languages and the preparation of teachers in primary schools." In Kashoki M.E and S. Ohannessian (eds.) Language in Zambia. London: International African Institute. pp. 292-328.

Sakala, J. (2012). Factors contributing to excess use of the lecture method among high school teachers in selected schools of kabwe and kalulushi districts: Lessons for educational administrators. Unpublished Master's Dissertation. University of Zambia.

Sidambi, J. J. (2011). The teaching of composition writing in zambian high schools: The case of two schools in Choma district. Unpublished Master's Dissertation. University of Zambia.

Tripathi, P. D. (1990). English in Zambia: The nature and prospects of one of Africa's New Englishes. In English Today, 6(3): 3438.

Wakumelo, M. N., 2013. "A critical analysis of Zambia's language-in education policy: Challenges and lessons learned." In $H$. Mcllwraith (ed). Multilingual Education in Africa: Lessons from the Juba Language in Education Conference, British Council. 